\title{
Effect of In-Mold Annealing on the Properties of Asymmetric Poly(L-lactide)/Poly(D-lactide) Blends Incorporated with Nanohydroxyapatite
}

\author{
Martin Boruvka *(D), Cenek Cermak, Lubos Behalek (D) and Pavel Brdlik (1)
}

check for

updates

Citation: Boruvka, M.; Cermak, C.; Behalek, L.; Brdlik, P. Effect of

In-Mold Annealing on the Properties of Asymmetric

Poly(L-lactide)/Poly(D-lactide)

Blends Incorporated with

Nanohydroxyapatite. Polymers 2021,

13, 2835. https://doi.org/

$10.3390 /$ polym 13162835

Academic Editor: Vineet Kumar

Received: 4 August 2021

Accepted: 17 August 2021

Published: 23 August 2021

Publisher's Note: MDPI stays neutra with regard to jurisdictional claims in published maps and institutional affiliations.

Copyright: (c) 2021 by the authors. Licensee MDPI, Basel, Switzerland. This article is an open access article distributed under the terms and conditions of the Creative Commons Attribution (CC BY) license (https:// creativecommons.org/licenses/by/ $4.0 /)$.
Department of Engineering Technology, Faculty of Mechanical Engineering, Technical University of Liberec, Studenstka 2, 46117 Liberec, Czech Republic; cenek.cermak@tul.cz (C.C.); lubos.behalek@tul.cz (L.B.); pavel.brdlik@tul.cz (P.B.)

* Correspondence: martin.boruvka@tul.cz

Abstract: The proper choice of a material system for bioresorbable synthetic bone graft substitutes imposes strict requirements for mechanical properties, bioactivity, biocompatibility, and osteoconductivity. This study aims to characterize the effect of in-mold annealing on the properties of nanocomposite systems based on asymmetric poly(L-lactide) (PLLA)/Poly(D-lactide) (PDLA) blends at $5 \mathrm{wt}$ \% PDLA loading, which was incorporated with nano-hydroxyapatite (HA) at various concentrations $(1,5,10,15 \mathrm{wt}$.\%). Samples were melt-blended and injection molded into "cold" mold $\left(50{ }^{\circ} \mathrm{C}\right)$ and hot mold $\left(100{ }^{\circ} \mathrm{C}\right)$. The results showed that the tensile modulus, crystallinity, and thermal-resistance were enhanced with increasing content of HA and blending with $5 \mathrm{wt} . \%$ of PDLA. In-mold annealing further improved the properties mentioned above by achieving a higher degree of crystallinity. In-mold annealed PLLA/5PDLA/15HA samples showed an increase of crystallinity by $\sim 59 \%$, tensile modulus by $\sim 28 \%$, and VST by $\sim 44 \%$ when compared to neat hot molded PLLA. On the other hand, the \% elongation values at break as well as tensile strength of the PLLA and asymmetric nanocomposites were lowered with increasing HA content and in-mold annealing. Moreover, in-mold annealing of asymmetric blends and related nanocomposites caused the embrittlement of material systems. Impact toughness, when compared to neat cold molded PLLA, was improved by $\sim 44 \%$ with in-mold annealing of PLLA/1HA. Furthermore, fracture morphology revealed fine dispersion and distribution of HA at $1 \mathrm{wt} . \%$ concentration. On the other hand, HA at a high concentration of $15 \mathrm{wt} . \%$ show agglomerates that worked as stress concentrators during impact loading.

Keywords: poly(L-lactide); poly(D-lactide); stereocomplex; nanohydroxyapatite; nanocomposites; mechanical properties; impact resistance; heat resistance; crystallization

\section{Introduction}

As global society continues to grow, sustainability issues concerning our raw material systems arise as well. Sustainability coupled with the rising environmental concerns and fossil resources depletion present considerable challenges for the polymer industry [1]. To alleviate these problems, governments in many countries are enacting laws that encourage the use of recycled, renewable, and biodegradable polymers [2]. Particularly in Europe, topics such as greenhouse gas emission, $\mathrm{CO}_{2}$ neutrality, renewability, embodied energy, toxicity, and resource depletion are driven by regulations.

At the same time, new sustainability platforms arise as well. An example is Think 2030, which is based at the Institute for European Environmental Policy (IEEP) and will produce science-based agenda recommendations for European environmental policy beyond 2020 [3].

Biobased polymers have been attracting attention as renewable materials that can replace conventional polymers, which are synthesized from unsustainable fossil based resources [4]. Among these, polylactide (PLA) has exhibited vast appeal in the past decades 
due to its good mechanical properties, renewability, biodegradability, and biocompatibility. The price of PLA is only slightly higher compared to the average commercial polymers and is likely to decline further with increasing demand [5]. PLA belongs to the family of compostable aliphatic polyesters which are derived from renewable biomass resources. Lactic acid (LA), which is the simplest $\alpha$-hydroxy acid, is the basic building block of PLA. Due to a chiral carbon atom of LA, PLA has two stereoisomeric forms: poly(L-lactide) (PLLA) and poly(D-lactide) (PDLA) [6]. Materials with variable optical and physio-chemical properties can be produced via controlling the proportion of the L- and D-enantiomers. This allows the production of relatively wide spectra of stereoisomeric PLA forms to match performance requirements [7]. Despite this, the application possibilities of PLA have been still limited notably due to slow crystallization rate, low heat, and impact resistance. Substantial efforts to address these issues have been undertaken to improve property deficiency. To achieve this, research is being carried out to develop modified PLA systems by blending, plasticization, copolymerization, and the addition of different types of fillers [8].

One of the most effective methods to enhance heat resistance, thermal stability, mechanical performance, and hydrolysis resistance of PLA is the formation of stereocomplex (SC) crystallites between enantiomeric PLLA and PDLA [9-11]. This unique idea was at first reported by Ikeda et al. [12] in 1987. Since then, numerous studies have been made on PLA stereocomplex due to its higher thermal and mechanical properties [13-16]. Furthermore, improved rheology and crystallization kinetics have been reported by Yamane et al. [17], Inkinen et al. [18], and Shi et al. [19] through the investigation of asymmetric PLLA/PDLA blends. Wei et al. [20] revealed at his research by self-nucleation experiments and polarized light microscopy (POM) observations, that the highest nucleation density of PLLA/PDLA blends was achieved through incorporation of PDLA with a concentration of $5 \mathrm{wt} . \%$. Subsequently, Wang et al. [21] observed the formation of a highly interconnected honeycomb network of SC crystallites through selective dissolution of asymmetric PLLA/PDLA blends with high-molecular-weight PDLA as a minor component. Pronounced crystallization of PLLA due to enhanced nucleation was observed at $5 \mathrm{wt} . \%$ loading of PDLA.

Since the 1950s, PLA has been widely investigated for applications such as drug delivery systems, surgical sutures, three-dimensional scaffolds for tissue engineering, bone implants, and bone fixation devices [22]. Despite its good biocompatibility and bioresorbability, insufficient mechanical strength of pure PLA limits its use in applications such as bone tissue engineering [23]. Furthermore, PLA is not osteoconductive and lacks bone-bonding ability such as bioactive ceramics and glasses [24]. To address this issue, nano-inorganic fillers [25-28] were introduced into biopolymers to prepare composites which could mimic the structure and function of the extracellular matrix (ECM) and support cell adhesion, proliferation, differentiation [29]. Among these nanofillers, hydroxyapatite (HA) $\left(\mathrm{Ca}_{10}\left(\mathrm{PO}_{4}\right)_{6}(\mathrm{OH})_{2}\right)$ has been used due to its excellent bioactivity, biocompatibility, and osteoconductivity [30-32]. Despite their several benefits, PLA/HA biocomposites often present some shortcomings in terms of performance [33]. HA nanoparticles tend to aggregate in PLA biocomposites because the surface energy of HA is much higher than that of PLA. Šupová [34] discussed several approaches to overcome the dispersion problem of hydroxyapatite particles in polymer matrices. Therefore, recent research have focused on improving the mechanical and thermal properties of PLA/HA biocomposites through surface and impact modifications $[35,36]$. Furthermore, the interfacial adhesion of PLA/HA has been improved by grafting PLA to HA through ring-opening polymerization (ROP) of lactide [37-39]. Surface modification of HA has been conducted by Akindoyo et al. [33] through incorporation of $2 \mathrm{wt} . \%$ dicopper hydroxide phosphate (Fabulase 361). Shuai et al. [40] used 2-carboxyethylphosphonic acid (CEPA) coupling agent to modify the surface of HA particles. Homogeneous dispersion of CEPA modified HA(C-HA) in PLA matrix with improved interfacial interaction was observed in the study. On the other hand, Ferri et al. [41] reported that well performed melt extrusion and subsequent injection molding of PLA/HA biocomposites (10-30 wt.\% HA) enhanced 
thermo-mechanical properties of resulted nanocomposites. Nevertheless, increasing the HA content also resulted in reduced ability for energy absorption at impact conditions.

The primary objective of this study was to examine the influence of nanohydroxyapatite (HA) at various concentrations on the properties of asymmetric PLLA/PDLA blends. The novelty of this work is the study of the in-mold annealing effect of on the crystallization, mechanical properties, fractured morphology, and temperature and impact resistance of injection molded nanocomposites. The work also explores the usefulness of prolonged melt-blending and with subsequent injection molding techniques to manufacture plastic parts for bioresorbable synthetic bone graft substitutes. Furthermore, the influence of specific stereocomplex interactions on the dispersion and distribution of HA within asymmetric blends is discussed.

\section{Materials and Methods}

\subsection{Materials}

The PLA grades used in this study were purchased in the form of granules from Total Corbion PLA (Gorinchem, Netherlands). As a base matrix we used Luminy L130 ( $\geq 99 \%$ L-isomer), and Luminy D070 ( $\geq 99 \%$ D-isomer) was used as a nucleating agent for stereocomplexation. Onwards from here both will be abbreviated as PLLA and PDLA, respectively. Hydroxyapatite powder under the trade name CA-PATOH-018-NP with an average particle size less than $100 \mathrm{~nm}$ and stereochemical purity of $98.5 \%$ was purchased from American Elements (Los Angeles, California, USA). Nanohydroxyapatite will be from here abbreviated as HA.

\subsection{Samples Preparation}

Neat PLLA, asymmetric PLLA/PDLA blends, PLLA/HA nanocomposites, and PLLA/ PDLA/HA nanocomposites were prepared through melt-blending using MC 15 HT (Xplore, Sittard, Netherlands) microcompounder. Polymer granules and HA powder were dried in a VDB3 vacuum oven (Binder, Tuttlingen, Germany) at $80^{\circ} \mathrm{C}$ for $12 \mathrm{~h}$, prior to processing. Dispersion and distribution of HA has been controlled through stabilization of double screw torque. Samples were melt-blended for at least 5 min (depending on HA concentration) using built-in recirculation channel with a pair of conical screws (set to $100 \mathrm{rpm}$ ). Melting chamber temperatures has been set as constant $200{ }^{\circ} \mathrm{C}$ for PLLA based samples and $240{ }^{\circ} \mathrm{C}$ for PLLA/5PDLA based samples. After stabilizing the torque value (after at least $5 \mathrm{~min}$ ), the recirculation valve has been switched and the homogenized melt was forced into the portable heated chamber of the injection molding machine IM12 (Xplore, Sittard, Netherlands). The chamber of the injection molding machine has been set to a temperature $5^{\circ} \mathrm{C}$ higher than the microcompounder melting chamber. The injection process was divided into two parts; the first was an injection into a cold mold $\left(50^{\circ} \mathrm{C}\right)$ and the second was injection into a hot mold $\left(100^{\circ} \mathrm{C}\right)$. We are aware that term "cold mold" is not appropriate for temperatures as high as $50^{\circ} \mathrm{C}$, however it is used just for simplification reasons. Injection molds without cooling systems are regularly heated to a specific temperature after several cycles. Due to this we chose $50{ }^{\circ} \mathrm{C}$ as a base temperature. So, the processes differ only in the temperature of the mold and in the time after which the mold was removed from the machine, and the test specimens were released. The samples from cold mold were released immediately after injection molding, and samples from hot mold $\left(100^{\circ} \mathrm{C}\right)$ were allowed to crystallize within the mold for a further $120 \mathrm{~s}$ before demolding. During the injection molds were used to prepare standardized dumbbell tensile samples of 1B type according to the ISO 178 standard and test samples with dimensions of $80 \times 10 \times 4 \mathrm{~mm}^{3}$ according to the ISO 180 standard. The final concentrations of injection molded samples are listed in Table 1. 
Table 1. Sample compositions.

\begin{tabular}{cccc}
\hline Sample Code & PLLA (wt.\%) & PDLA (wt.\%) & HA (wt.\%) \\
\hline PLLA & 100 & - & - \\
PLLA/1HA & 99 & - & 1 \\
PLLA/5HA & 95 & - & 5 \\
PLLA/10HA & 90 & - & 10 \\
PLLA/15HA & 85 & - & 15 \\
PLLA/5PDLA & 95 & 5 & - \\
PLLA/5PDLA/1HA & 94 & 5 & 1 \\
PLLA/5PDLA/5HA & 90 & 5 & 5 \\
PLLA/5PDLA/10HA & 85 & 5 & 10 \\
PLLA/5PDLA/15HA & 80 & 5 & 15 \\
\hline
\end{tabular}

\subsection{Differential Scanning Calorimetry (DSC)}

Non-isothermal crystallization of the samples was characterized using DSC 1/700 (Mettler Toledo, Greifensee, SWITZERLAND). Measurements were performed on the middle part of tensile sample cross-sections $(8 \pm 0.5 \mathrm{mg})$, which were prepared by RM 2255 microtome (Leica, Nußloch, GERMANY). Samples were heated from $0{ }^{\circ} \mathrm{C}$ to $200{ }^{\circ} \mathrm{C}$ (PLLA/PDLA based samples up to $240{ }^{\circ} \mathrm{C}$ ) at a $10{ }^{\circ} \mathrm{C} \cdot \mathrm{min}^{-1}$ heating rate, then kept isothermal for $3 \mathrm{~min}$ to remove previous thermal history, and then cooled back to $0{ }^{\circ} \mathrm{C}$ under $10^{\circ} \mathrm{C} \cdot \mathrm{min}^{-1}$ cooling rate to observe melt crystallization. Analysis was performed under nitrogen flow rate of $50 \mathrm{ml} \cdot \mathrm{min}^{-1}$. The following were recorded from the first heating phase: glass transition temperature $\left(T_{\mathrm{g}}\right)$; cold crystallization temperature $\left(T_{\mathrm{cc}}\right)$ and enthalpy $\left(\Delta H_{\mathrm{cc}}\right)$; pre-melting recrystallization temperature $\left(T_{\mathrm{rc}}\right)$ and enthalpy $\left(\Delta H_{\mathrm{rc}}\right)$; homocrystallite melting temperature $\left(T_{\mathrm{hm}}\right)$ and enthalpy $\left(\Delta H_{\mathrm{hm}}\right)$; stereocomplex crystallite melting temperature $\left(T_{\mathrm{scm}}\right)$ and enthalpy $\left(\Delta H_{\mathrm{scm}}\right)$. Parameters of the above-mentioned temperatures and enthalpies were taken as the peak temperatures and the areas of the melting endotherms or crystallization exotherms, respectively.

Crystallinity degrees $\left(\chi_{c}\right)$ of neat PLLA and PLLA/HA nanocomposites were calculated as follows [42]:

$$
\chi_{c}=\frac{\Delta H_{h m}-\Delta H_{c c}-\Delta H_{r c}}{\Delta H_{h m}^{0} \cdot W_{m}} \cdot 100[\%]
$$

where $\Delta H^{0}{ }_{\mathrm{hm}}$ is the melting enthalpy of $100 \%$ crystallized PLLA $\left(106 \mathrm{~J} \cdot \mathrm{g}^{-1}\right)$ [43] and $W_{\mathrm{m}}$ is the weight fraction of PLLA.

Crystallinity degree $\left(\chi_{\mathrm{c}}\right)$ of asymmetric PLLA/PDLA blends and PLLA/PDLA/HA nanocomposites was calculated as follows [44]:

$$
\chi_{c}=\frac{\Delta H_{h m}+\Delta H_{s c m}-\Delta H_{c c}-\Delta H_{r c}}{\Delta H_{(h+s c) m}^{0} \cdot W_{m}} \cdot 100 \quad[\%]
$$

where $\Delta H^{0}{ }_{(\mathrm{h}+\mathrm{sc}) \mathrm{m}}$ is a calculated melting enthalpy based on $100 \%$ crystallized PLLA and stereocomplexed PLA (scPLA). Since the theoretical value is different for PLLA homocrystallites $(\alpha)\left(106 \mathrm{~J} \cdot \mathrm{g}^{-1}\right)$ and stereocomplexed crystallites $(\eta)\left(142 \mathrm{~J} \cdot \mathrm{g}^{-1}\right)$ [44], it can be postulated that $\Delta H^{0}{ }_{(\mathrm{h}+\mathrm{sc}) \mathrm{m}}$ value varies with relative amount of both $\alpha$ and $\eta$ crystallite forms as follows:

$$
\Delta H_{(h+s c) m}^{0}=\Delta H_{h m}^{0} \cdot X_{h}+\Delta H_{s c m}^{0} \cdot X_{s c}\left[\mathrm{~J} \cdot \mathrm{g}^{-1}\right],
$$

where $\Delta H^{0}$ scm is melting enthalpy of $100 \%$ crystallized scPLA $\left(142 \mathrm{~J} \cdot \mathrm{g}^{-1}\right)$. Values of $X_{\mathrm{h}}$ and $X_{\mathrm{sc}}$ are then relative amounts of $\alpha$ and $\eta$ crystallites developed during non-isothermal crystallizations and can be calculated based on enthalpy values from DSC scans (see Table X) in the following manner.

$$
X_{h}=\frac{\Delta H_{h m}}{\Delta H_{h m}+\Delta H_{s c m}},
$$




$$
X_{s c}=\frac{\Delta H_{s c m}}{\Delta H_{h m}+\Delta H_{s c m}}
$$

\subsection{Mechanical Measurement}

Tensile strength $\left(\sigma_{\mathrm{m}}\right)$, elongation at break $\left(\varepsilon_{\mathrm{tb}}\right)$, and Young's modulus $\left(E_{\mathrm{t}}\right)$ were measured by using a TIRA test 2300 (Tira, Schalkau, Germany) universal testing machine equipped with a load cell of $10 \mathrm{kN}$ and extensometer MFX 500-B (Mess \& Feinwerktechnik, $\mathrm{GmbH}$, Velbert, Germany). Measurements have been performed according to the ISO 527 standard. Tensile strength and elongation at break measurements were performed at a crosshead speed of $5 \mathrm{~mm} \cdot \mathrm{min}^{-1}$ and Young's modulus at a crosshead speed of $1 \mathrm{~mm} \cdot \mathrm{min}^{-1}$. All the samples were prior to testing conditioned in a KSP climatic chamber (Teseco, Kostelec nad Orlici, Czech Republic) according to ISO 291 at $23{ }^{\circ} \mathrm{C}$ and $50 \%$ relative humidity for 4 days. Each batch of $1 \mathrm{~B}$ type dumbbell specimens was subjected to 10 repetitive tests under an ambient temperature of $23^{\circ} \mathrm{C}$.

\subsection{Impact Resistance}

Charpy impact strength $\left(a_{\mathrm{cU}}\right)$ was measured using a Resil 5.5 (Ceast, Pianezza, Italy) testing machine according to ISO $179-1 / 1 \mathrm{eU}$ standard. A pendulum with the nominal energy of $5 \mathrm{~J}$ and $2.9 \mathrm{~m} \cdot \mathrm{s}^{-1}$ striking velocity was used. Unnotched samples $\left(80 \times 10 \times 4 \mathrm{~mm}^{3}\right)$ were used, and each batch was subjected to 10 repetitive tests under an ambient temperature of $23^{\circ} \mathrm{C}$.

\subsection{Thermo-Mechanical Analysis}

Heat deflection temperature (HDT) measurements were conducted according to ISO 75-2 standard on HDT/Vicat 6-300 Allround (Zwick/Roell, Ulm, Germany). Method A using a flexural stress of $1.8 \mathrm{MPa}$ was applied, and each batch of samples $\left(80 \times 10 \times 4 \mathrm{~mm}^{3}\right)$ was subjected to 5 repetitive tests at a heating rate of $120^{\circ} \mathrm{C} \cdot \mathrm{h}^{-1}$.

Vicat softening temperature (VST) measurements were conducted according to ISO 306 using the above mentioned equipment. Method B120 using a force of $50 \mathrm{~N}$ and a heating rate of $120^{\circ} \mathrm{C} \cdot \mathrm{h}^{-1}$ was applied on each batch of samples $(4 \mathrm{~mm}$ thick grip section of dumbbell specimens). Samples were subjected to 5 repetitive tests.

\subsection{Morphological Characteristic}

Morphology of fractured surfaces was examined by field emission scanning electron microscopy (FE-SEM) TESCAN MIRA 3 (Tescan, Brno, Czech Republic) with an accelerated voltage of $2 \mathrm{kV}$. Unnotched samples were frozen overnight $\left(-50^{\circ} \mathrm{C}\right)$ and then crushed using a Resil 5.5 (Ceast, Pianezza, Italy) impact testing machine. A pendulum with the nominal energy of $5 \mathrm{~J}$ and $2.9 \mathrm{~m} \cdot \mathrm{s}^{-1}$ striking velocity was used. Fractured surfaces were coated with $2 \mathrm{~nm}$ of platinum/palladium $(\mathrm{Pt} / \mathrm{Pd})$ alloy $(80 / 20)$ using a sputter coater LEICA EM ACE200 (Leica, Wetzlar, Germany).

\section{Results and Discussion}

\subsection{Non-Isothermal Crystallization (DSC Measurements)}

The prepared samples were studied by non-isothermal DSC analysis. During the first heating, the influence of the injection molding technological conditions and the promoting effect of nucleating agents (PDLA, HA) on the thermal properties and crystallization was investigated. The subtracted data obtained from the DSC measurements, including the calculated degree of crystallinity, are presented in Table 2 (SF) and Table 3 (TF). DSC thermograms of the samples injected into the cold $\left(50{ }^{\circ} \mathrm{C}\right)$ and hot $\left(100{ }^{\circ} \mathrm{C}\right)$ molds are shown in Figures 1 and 2. Figure 1 shows the DSC curves of samples with PLLA and $\mathrm{HA}(1,5,10$, and $15 \mathrm{wt} . \%)$ which were injected into cold $\left(50^{\circ} \mathrm{C}\right)$ and hot molds $\left(100{ }^{\circ} \mathrm{C}\right)$. PLLA exhibits a characteristic glass transition temperature $\left(T_{\mathrm{g}}\right)$, two exothermic peaks, which can be attributed to cold crystallization $\left(T_{\mathrm{cc}}\right)$ and recrystallization before melting $\left(T_{\mathrm{rc}}\right)$ and melting of homocrystalites $\left(T_{\mathrm{hm}}\right)$. This observation indicates the capability of 
PLLA chains to undergo further rearranging and recrystallization before melting. Both of these resulted from a slow crystallization process as PLLA was unable to crystallize properly during cooling. Samples from cold and hot molds exhibit nearly the same trends, which signify that chosen conditions for neat PLLA from hot mold were insufficient for the significant increase in crystallinity degree (see Tables 1 and 2). On the other hand, PLLA samples incorporated with HA showed enhancement of the crystallization rate at both injection molding conditions. Enhanced crystallization after the introduction of HA was also observed by Akindoyo et al. [36]. Nanocomposites from cold molds exhibited with increasing content of HA a shift of $T_{\mathrm{cc}}$ to lower temperatures as well as a decrease of $\Delta H_{\mathrm{cc}}$. This clearly indicates the nucleation efficiency of HA. The degree of crystallinity of PLLA/15HA samples increased from 12.0 to $17.9 \%$ when compared to neat PLLA. Furthermore, in-mold annealing at $100{ }^{\circ} \mathrm{C}$ mold worked synergistically with increasing content of HA on the crystallization of PLLA. Hydrogen bonding interactions between PDLLA and HA has been reported by Zhou et al. [45]. Moreover, synergistic effects of chain dynamics and enantiomeric interaction on the crystallization in PDLA/PLLA mixtures has been observed by Lv et al. [46]. Therefore, the formation of multiple hydrogen bonding between the enantiomers of polylactide $\left(\mathrm{CH}_{3} \cdots \mathrm{O}\right.$ interactions $)$ and their $\mathrm{C}=\mathrm{O}$ group with the $\mathrm{P}-\mathrm{OH}$ group of HA could be behind this phenomenon. However, further study to explore this phenomenon should be conducted. Samples containing $15 \mathrm{wt} . \%$ of HA resulted in crystallization of PLLA to the extent that no cold crystallization has been observed during heating. The degree of crystallinity of in-mold annealed PLLA/15HA samples increased from 16.2 to $44.4 \%$ when compared to neat PLLA. As shown in Figure 2, cold crystallization peaks of asymmetric PLLA/5PDLA blend and related nanocomposite samples from cold mold exhibited the same trend. When compared to neat PLLA, $T_{\mathrm{cc}}$ shifted from $100{ }^{\circ} \mathrm{C}$ to $89^{\circ} \mathrm{C}$ and remained unchanged with increasing content of the HA. Asymmetric blend and PLLA/5PDLA/1HA nanocomposites showed approximately the same cold crystallization enthalpy. However, with a further increase of the HA concentration, the cold crystallization peak became slightly weaker. This observation indicates that the nucleation effect of HA was inhibited due to the formation of stereocomplex (SC) crystallites, which hindered the mobility of PLLA macromolecular chains. A decrease in macromolecular chain the mobility due to low PDLA concertation in PLLA was observed by Shi et al. [19]. Based on these results, Shi postulated that formed SC crystallites worked as the physical crosslinking sites where segments of a number of the core of PLLA chains are formed. Due to this, only a part of the PLLA chains participated in the SC crystallites, which resulted in limited mobility of those PLLA chains. Furthermore, Yamane et al. [17] observed that in the presence of SC crystallites can be melted PLLA polymer significantly reinforced, showing a strong strain hardening feature. This indicates that the reserved SC crystallites can also serve as a rheological modifier to improve the low melt strength of PLLA. Furthermore, samples from cold mold exhibited small exothermic recrystallization peaks due to previous cold crystallization. Besides, endothermic homocrystallite melting peaks $\left(T_{\mathrm{hm}}\right)$ at around $175^{\circ} \mathrm{C}$ were also observed, with small endothermic melting peaks of stereocomplexed crystallites $\left(T_{\mathrm{scm}}\right)$ at around $220^{\circ} \mathrm{C}$. Enthalpy values $\left(\Delta H_{\mathrm{scm}}\right)$ of stereocomplexed crystallites varied only slightly and did not increase with a higher HA content. Therefore, the HA has no positive effect of promoting selective stereocomplexation. All of the in-mold annealed asymmetric PLLA/5PDLA blend and related nanocomposite samples fully crystallized during processing, and no cold crystallizations or recrystallizations has been observed. Enthalpy values of the in-mold annealed stereocomplexed crystallites remained unchanged with the incorporation of HA. 
Table 2. Non-isothermal crystallization data of samples from cold mold $\left(50^{\circ} \mathrm{C}\right)$.

\begin{tabular}{|c|c|c|c|c|c|c|c|c|c|}
\hline Samples & $T_{\mathrm{cc}}\left({ }^{\circ} \mathrm{C}\right)$ & $\begin{array}{c}\Delta H_{\mathrm{cc}} \\
\left(\mathrm{J} \cdot \mathrm{g}^{-1}\right)\end{array}$ & $T_{\text {rc }}\left({ }^{\circ} \mathrm{C}\right)$ & $\begin{array}{c}\Delta H_{\mathrm{rc}} \\
\left(\mathrm{J} \cdot \mathrm{g}^{-1}\right)\end{array}$ & $T_{\mathrm{hm}}\left({ }^{\circ} \mathrm{C}\right)$ & $\begin{array}{c}\Delta H_{\mathrm{hm}} \\
\left(\mathrm{J} \cdot \mathrm{g}^{-1}\right)\end{array}$ & $T_{\mathrm{scm}}\left({ }^{\circ} \mathrm{C}\right)$ & $\begin{array}{l}\Delta H_{\mathrm{scm}} \\
\left(\mathrm{J} \cdot \mathrm{g}^{-1}\right)\end{array}$ & $\chi_{c}(\%)$ \\
\hline PLLA & 100.2 & 33.7 & 159.1 & 5.7 & 174.9 & 52.2 & - & - & 12.0 \\
\hline PLLA/1HA & 95.4 & 29.5 & 158.0 & 7.0 & 176.0 & 49.3 & - & - & 13.7 \\
\hline PLLA/5HA & 93.3 & 25.8 & 158.1 & 6.0 & 177.9 & 47.5 & - & - & 15.6 \\
\hline PLLA/10HA & 91.4 & 24.9 & 158.1 & 5.6 & 177.3 & 46.1 & - & - & 16.4 \\
\hline PLLA/15HA & 89.7 & 22.4 & 158.0 & 4.5 & 175.1 & 43.1 & - & - & 17.9 \\
\hline PLLA/5PDLA & 88.4 & 23.1 & 157.0 & 4.4 & 174.4 & 44.5 & 221.7 & 8.6 & 16.1 \\
\hline PLLA/5PDLA/1HA & 89.4 & 23.8 & 157.0 & 4.6 & 174.5 & 43.9 & 221.2 & 7.6 & 14.8 \\
\hline PLLA/5PDLA/5HA & 89.2 & 20.1 & 157.3 & 3.4 & 173.9 & 38.0 & 222.1 & 11.5 & 14.5 \\
\hline PLLA/5PDLA/10HA & 88.5 & 20.6 & 157.1 & 3.2 & 174.1 & 38.2 & 222.0 & 12.8 & 15.1 \\
\hline PLLA/5PDLA/15HA & 88.4 & 19.1 & 157.4 & 2.5 & 173.7 & 35.9 & 221.8 & 9.5 & 15.8 \\
\hline
\end{tabular}

Table 3. Non-isothermal crystallization data of samples from hot mold $\left(100{ }^{\circ} \mathrm{C}\right)$.

\begin{tabular}{|c|c|c|c|c|c|c|c|c|c|}
\hline Samples & $T_{\mathrm{cc}}\left({ }^{\circ} \mathrm{C}\right)$ & $\begin{array}{c}\Delta H_{\mathrm{cc}} \\
\left(\mathrm{J} \cdot \mathrm{g}^{-1}\right)\end{array}$ & $T_{\text {rc }}\left({ }^{\circ} \mathrm{C}\right)$ & $\begin{array}{c}\Delta H_{\mathrm{rc}} \\
\left(\mathrm{J} \cdot \mathrm{g}^{-1}\right)\end{array}$ & $T_{\mathrm{hm}}\left({ }^{\circ} \mathrm{C}\right)$ & $\begin{array}{c}\Delta H_{\mathrm{hm}} \\
\left(\mathrm{J} \cdot \mathrm{g}^{-1}\right)\end{array}$ & $T_{\mathrm{scm}}\left({ }^{\circ} \mathrm{C}\right)$ & $\begin{array}{l}\Delta H_{\text {scm }} \\
\left(\mathrm{J} \cdot \mathrm{g}^{-1}\right)\end{array}$ & $\chi_{c}(\%)$ \\
\hline PLLA & 101.0 & 26.5 & 160.1 & 6.0 & 176.7 & 49.7 & - & - & 16.2 \\
\hline PLLA/1HA & 94.9 & 20.4 & 158.1 & 5.7 & 175.3 & 49.1 & - & - & 22.0 \\
\hline PLLA/5HA & 92.4 & 17.1 & 158.0 & 4.7 & 175.6 & 47.4 & - & - & 25.4 \\
\hline PLLA/10HA & 88.5 & 11.0 & 158.1 & 2.9 & 175.3 & 45.2 & - & - & 32.8 \\
\hline PLLA/15HA & - & - & 162.1 & 0.5 & 174.8 & 40.5 & - & - & 44.4 \\
\hline PLLA/5PDLA & - & - & - & - & 175.7 & 42.5 & 223.6 & 9.8 & 40.1 \\
\hline PLLA/5PDLA/1HA & - & - & - & - & 175.9 & 39.9 & 221.0 & 9.6 & 38.1 \\
\hline PLLA/5PDLA/5HA & - & - & - & - & 177.1 & 38.6 & 221.1 & 9.8 & 38.3 \\
\hline PLLA/5PDLA/10HA & - & - & - & - & 175.6 & 37.1 & 222.0 & 9.6 & 38.9 \\
\hline PLLA/5PDLA/15HA & - & - & - & - & 175.2 & 35.5 & 222.8 & 9.3 & 39.4 \\
\hline
\end{tabular}

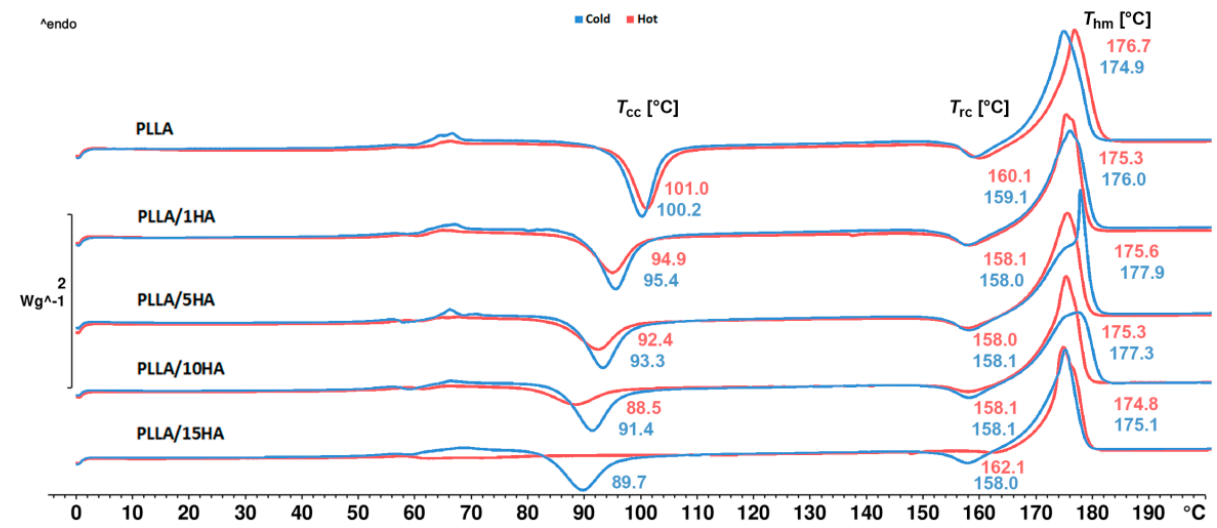

Figure 1. DSC curves of the PLLA a PLLA/HA nanocomposites obtained during the first heating.

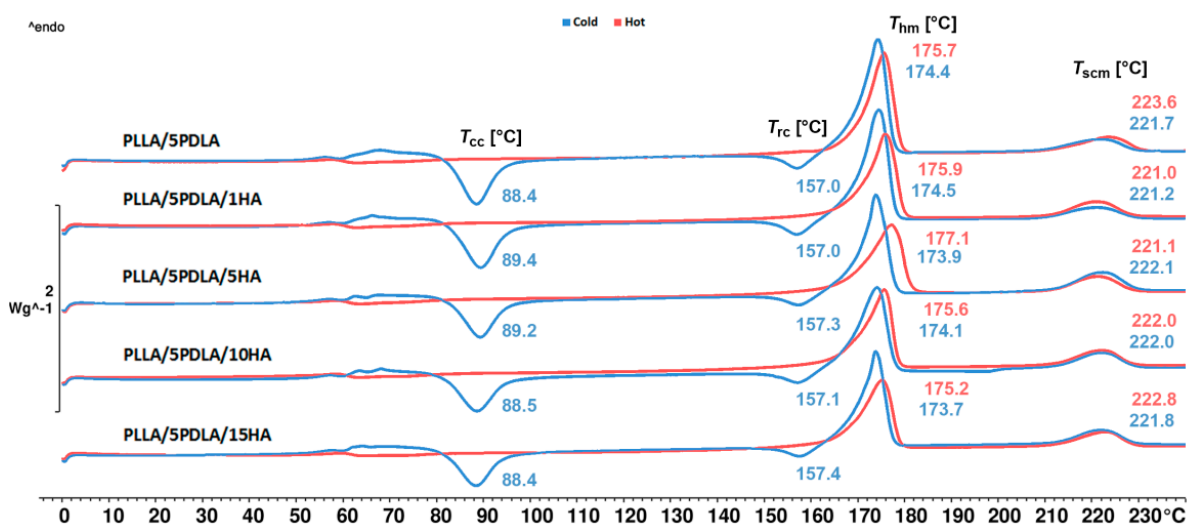

Figure 2. DSC curves of the asymmetric PLLA/5PDLA a PLLA/5PDLA/HA nanocomposites obtained during the first heating. 


\subsection{Mechanical Properties (Static Tensile and Charphy Impact Tests)}

The graph in Figure 3 shows that the value of the tensile modulus $\left(E_{\mathrm{t}}\right)$ increases with increasing hydroxyapatite content. For pure PLLA, the value of the tensile modulus after in-mold annealing is comparable to the samples originating from the cold mold. In-mold annealed samples based on PLLA matrix shows a slight increase in $E_{\mathrm{t}}$ when compared to samples from cold mold. Such an increase is related to a higher degree of crystallinity (see Tables 2 and 3). Furthermore, Ko et al. [39] observed the same trend using unmodified nano HA (up to $15 \mathrm{wt} . \%$ ) in PLA samples. In the case of asymmetric samples with $5 \mathrm{wt} . \%$ PDLA, the difference was more pronounced than for materials where the matrix contained only PLLA. The synergistic action of specific stereocomplex interactions and increased nucleation rate due to HA caused during the processing and development of the morphology an increase in the modulus of elasticity when compared to samples from cold mold. In-mold annealed PLLA/5PDLA/15HA samples show a $\sim 28 \%$ increase of $E_{\mathrm{t}}$ when compared to neat PLLA.

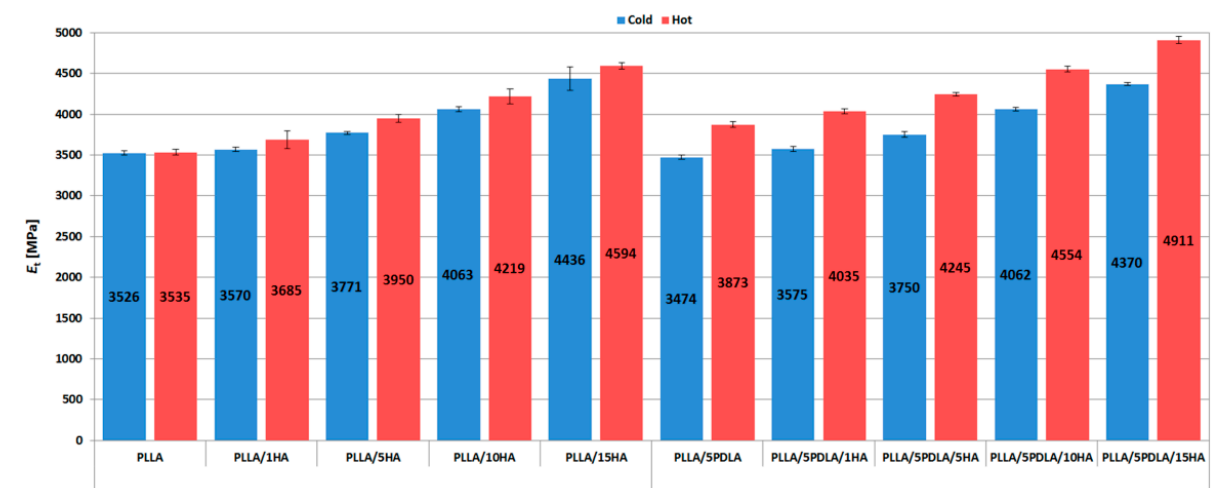

Figure 3. Tensile modulus plots of samples from cold and hot molds.

The resulting values of the tensile strength $\left(\sigma_{\mathrm{m}}\right)$ are shown in Figure 4 , which shows that in the case of samples originating from the cold mold, the value of the tensile strength hardly changes depending on the content of the HA. For the samples containing PLLA and $1 \% \mathrm{HA}$ that were injected into the hot mold, it can be seen that there was a slight increase in the value of the tensile strength compared to pure PLLA. In the case of the PLLA/5PDLA/1HA samples from the hot mold, the difference in strength is $17 \%$ higher compared to PLLA/5PDLA. The strength values of the materials gradually decrease with contents from $5 \%$ HA onwards. This is most likely due to the higher HA content, which agglomerated into larger clusters (see SEM fracture analysis). These agglomerates acted as structural defects and caused the anticipated failure of the samples under tensile stress. Furthermore, Vadori et al. [47] have shown that increasing the mold temperature of PLA decreases the impact toughness and ductility of PLA.

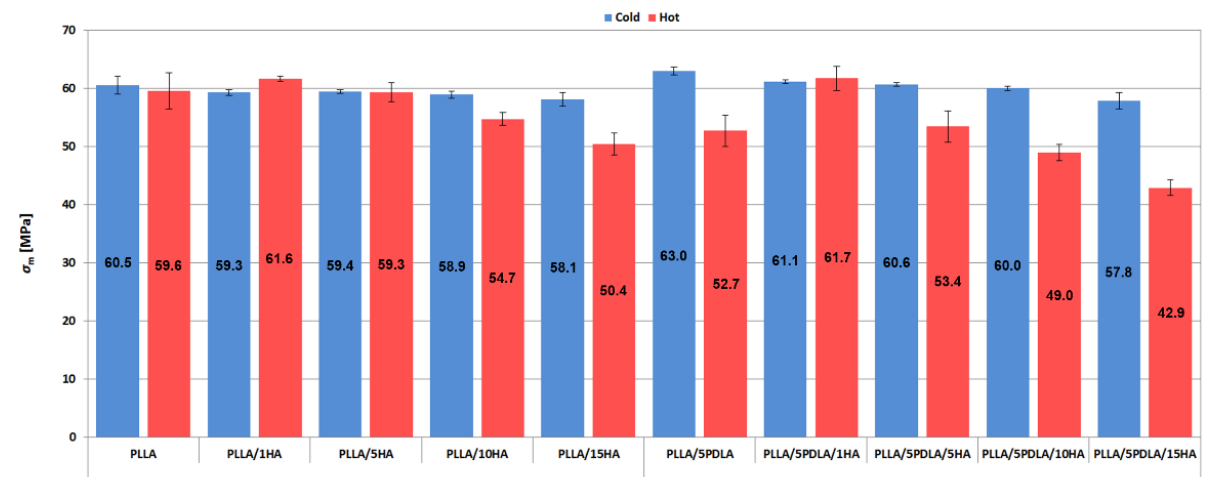

Figure 4. Tensile strength plots of samples from cold and hot molds. 
Elongation at break $\left(\varepsilon_{\mathrm{tb}}\right)$ plots (see Figure 5) showed the same trend; all in-mold annealed samples showed a sharp decrease in ductility. Furthermore, PLLA based samples from cold molds show an obvious decrease of $\varepsilon_{\mathrm{tb}}$ with increasing content of HA. Lower ductility of cold mold samples has also been observed after blending PLLA with 5\% of PDLA.

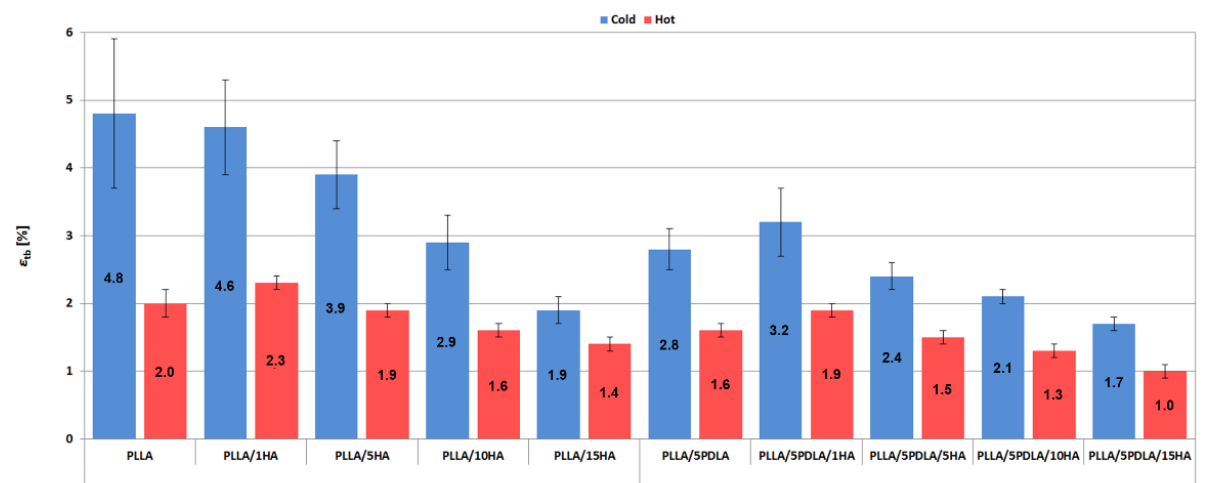

Figure 5. Elongation at break plots of samples from cold and hot molds.

From the plots in Figure 6 it can be seen that the in-mold annealed specimens with PLLA matrix have higher impact toughness $\left(a_{\mathrm{cU}}\right)$ compared to the specimens from the cold mold. The highest values were observed for in-mold annealed PLLA/1HA nanocomposites. The same trend has been observed by Kawamoto et al. [48] using different nucleation agents. High-temperature molding $\left(110^{\circ} \mathrm{C}\right)$ of PLLA and nucleating agents based on a mix of ethylenebis-(12-hydroxystearylamide) (EBHS)/talc (1 wt.\% each) and octamethylenedicarboxylicdibenzoylhydrazide $(\mathrm{OMBH})$ at $1 \mathrm{wt} \%$ loading. Furthermore, the value of impact toughness decreased with an increasing percentage of HA in PLLA. A similar trend of the impact toughness was observed for the samples originating from the hot mould with a base matrix containing $5 \mathrm{wt}$ \% PDLA.

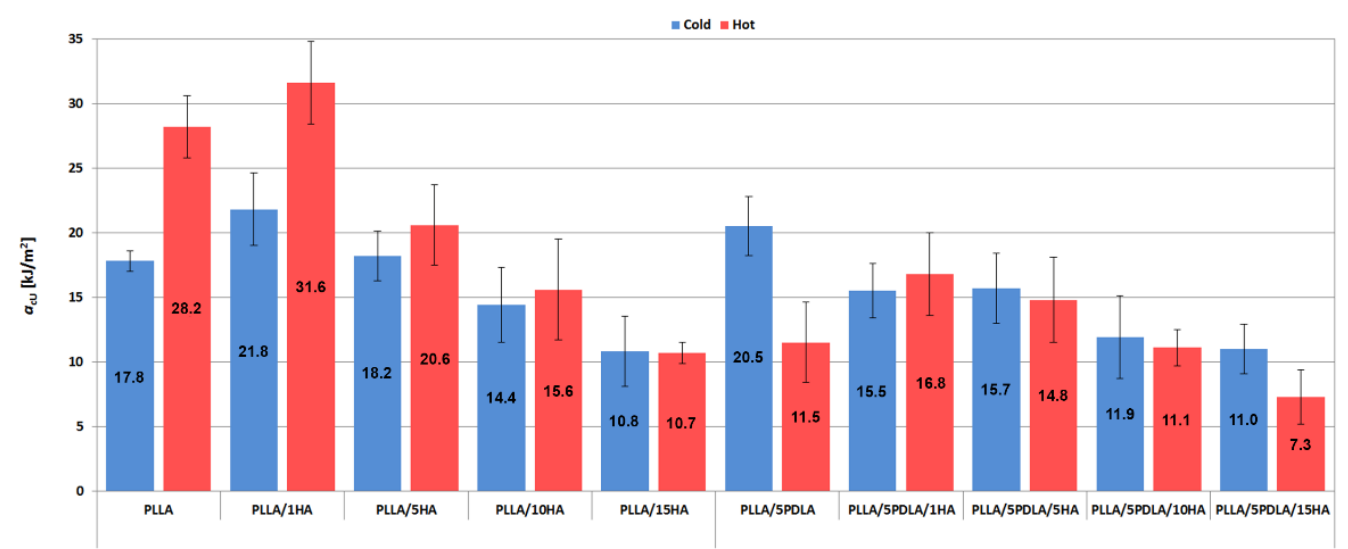

Figure 6. Impact toughness plots of samples from cold and hot molds.

An exception is the trend of values for samples from the cold mould containing PDLA. The highest impact toughness value has been observed for the pure biopolymer without adding HA component and onward decreases with increasing content. Enhanced impact toughness of annealed PLA with $1 \mathrm{wt}$ \% of ethylenebishydroxystearamide (EBH) has been observed by Tang et al. [49]. An increased number of spherulites with smaller size were believed to consume more energy and thus increase the impact strength of nucleated PLA samples.

\subsection{Thermo-Mechanical Properties (HDT and VST Measurements)}

The heat deflection temperature (HDT) and Vicat softening temperature (VST) of cold and hot molded samples are shown in Figures 7 and 8, respectively. VST is the temperature at which a material loses its stability form, and HDT is the temperature at which the 
material loses its load-bearing capacity. Both HDT and VST results of cold mold samples proved that a degree of crystallinity below $20 \%$ (see Tables 2 and 3) is insufficient to enhance thermal stability. The same results were reported by Ferri et al. [41]. Tang et al. [49] noticed enhanced HDT of PLA with 1\% EBH molded at room temperature and then annealed for 1, $2,4,10$, and $20 \mathrm{~min}$ at $105^{\circ} \mathrm{C}$. A threshold for crystallinity content was noticed when the crystallinity reached $25 \%$. Our in-mold annealed samples show the same trend. However, this phenomenon is more obvious from VST results where an in-mold annealed PLLA/5HA sample at $25.4 \%$ crystallinity reached VST of $75.6{ }^{\circ} \mathrm{C}$ and a cold mold sample at $15.6 \%$ crystallinity reached only $61.4^{\circ} \mathrm{C}$. The highest HDT increase of in-mold annealed samples without PDLA was noticed by $13 \%$ for PLLA/15HA and by $24 \%$ for PLLA/5PDLA/15HA samples when compared to hot mold neat PLLA.

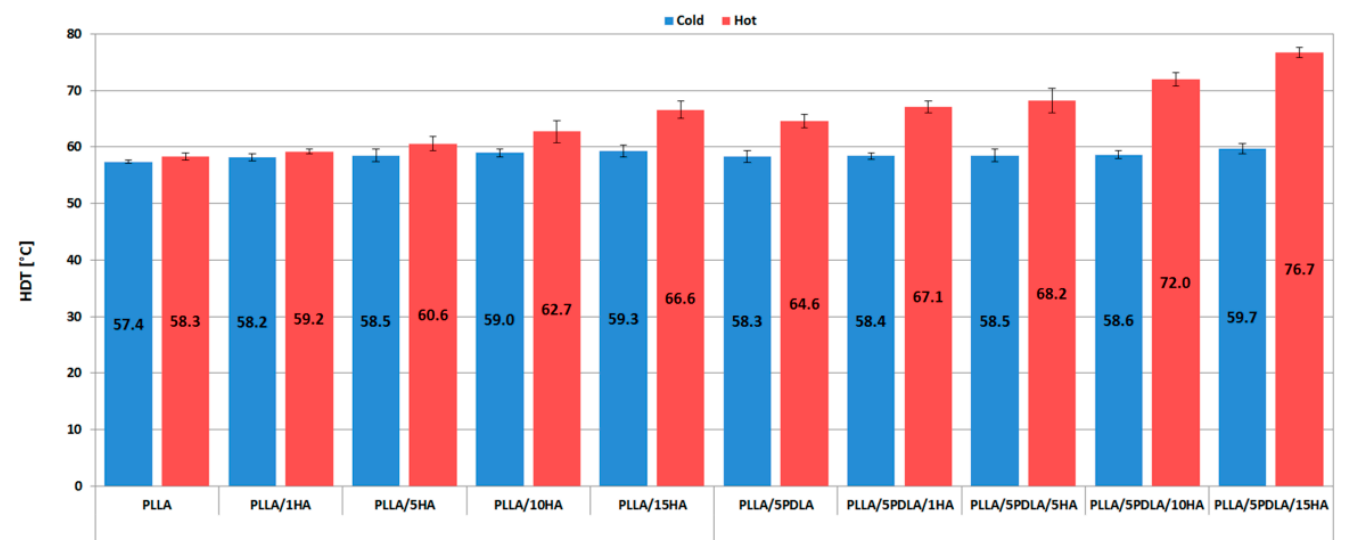

Figure 7. Heat deflection temperature plots of samples from cold and hot molds.

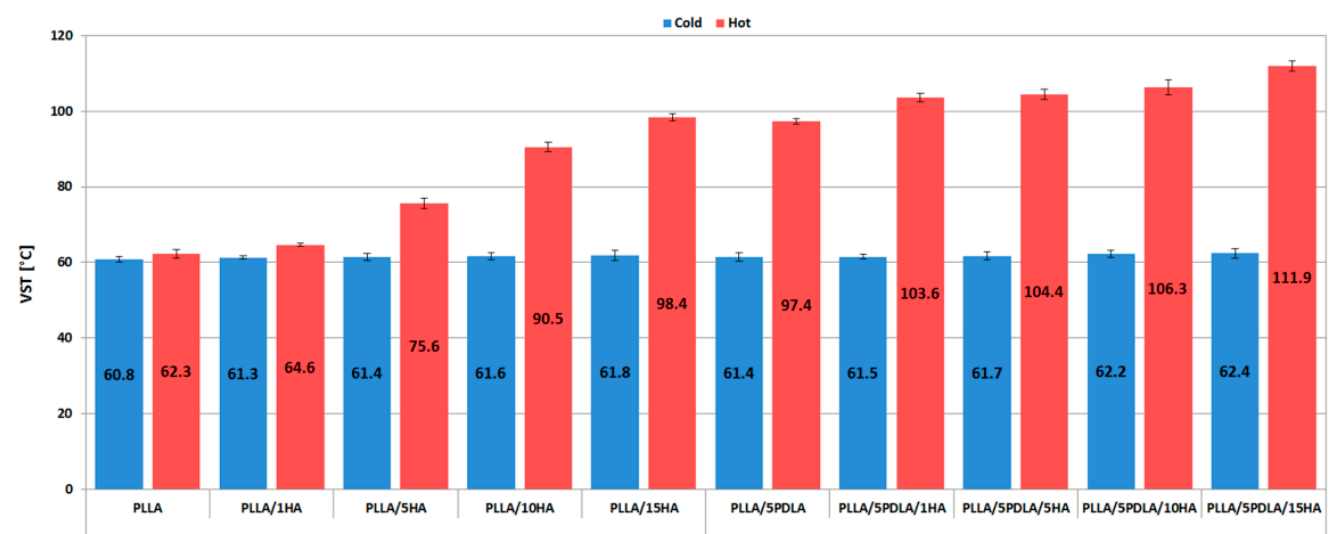

Figure 8. Vicat softening temperature plots of samples from cold and hot molds.

The same trend was noticed for VST, where PLLA/15HA increased by 37\% and PLLA/5PDLA/15HA by $44 \%$. These results prove that the developed morphology during in-mold annealing at $100{ }^{\circ} \mathrm{C}$ for 2 min worked synergistically, and enhanced temperature resistance was reached due to specific stereocomplex interactions at a low loading of PDLA (5 wt. \%) and relatively high HA loading (15 wt.\%).

\subsection{Fracture Surface Morphology (SEM Analysis)}

SEM analysis was used to evaluate the morphology of individual fracture surfaces of PLLA, asymmetric PLLA/5PDLA blends and their nanocomposites with different HA content. In particular, the influence of the preparation technology on the dispersion and distribution of the nanofiller and the fracture mechanism of the prepared samples were investigated. The following images show the PLLA samples that were prepared by injection moulding in the cold (Figure 9a) and hot (Figure 9b) molds. It is well known that in many 
applications, the fracture properties of amorphous polymers render them unsatisfactory. These fracture properties are linked to the stress-induced growth and breakdown of crazes, which are planar, crack-like defects [50]. In the case of amorphous PLLA, the primary deformation mechanism propagation comes from multiple craze formations with low initiation energy. On the other hand, in crystalline PLLA, deformation under impact loading takes place through the deformation of the crystallites with the contribution of cavitation and fibrillation mechanisms [51]. Figure 9 shows that cold mold PLLA sample with $12 \%$ crystallinity exhibits smoother surface fracture when compared to in-molded annealed PLLA with higher roughness and $16.2 \%$ crystallinity. Both details of fractured surfaces show few fibrils. Since the higher impact toughness was observed for in-mold annealed PLLA (see Figure 6), an increase of spherulites with smaller size most likely consumed more energy during fracture. An increase in surface roughness was assigned by Park et al. [52] to the increase of crystallinity. The fracture surface morphology of asymmetric PLLA/5PDLA blends, which were prepared by injection moulding in cold and hot molds is shown in Figure 10a,b, respectively. Both cold and hot mold samples similarly show brittle fracture failure without any indication of plastic deformation. The coarser failure structure with deep concavities of the in-mold annealed samples reflects a higher degree of crystallinity (see Tables 2 and 3). However, the impact toughness of these samples is much lower compared to the cold mold samples. Related to the spherulite structure of crystalline polymers, two possible crack paths should be considered: one is the inter-spherulitic crack growth, and the other the crack growth through spherulites. The polymer crystal structure related crack paths strongly depend on the formation process of the microstructure $[53,54]$. A more detailed study is required to clarify the effect of PDLA on homocrystallization and the formation of stereocomplexed structure, which resulted in subsequent failure and different crack propagation of cold and hot molded asymmetric PLLA/5PDLA blends.
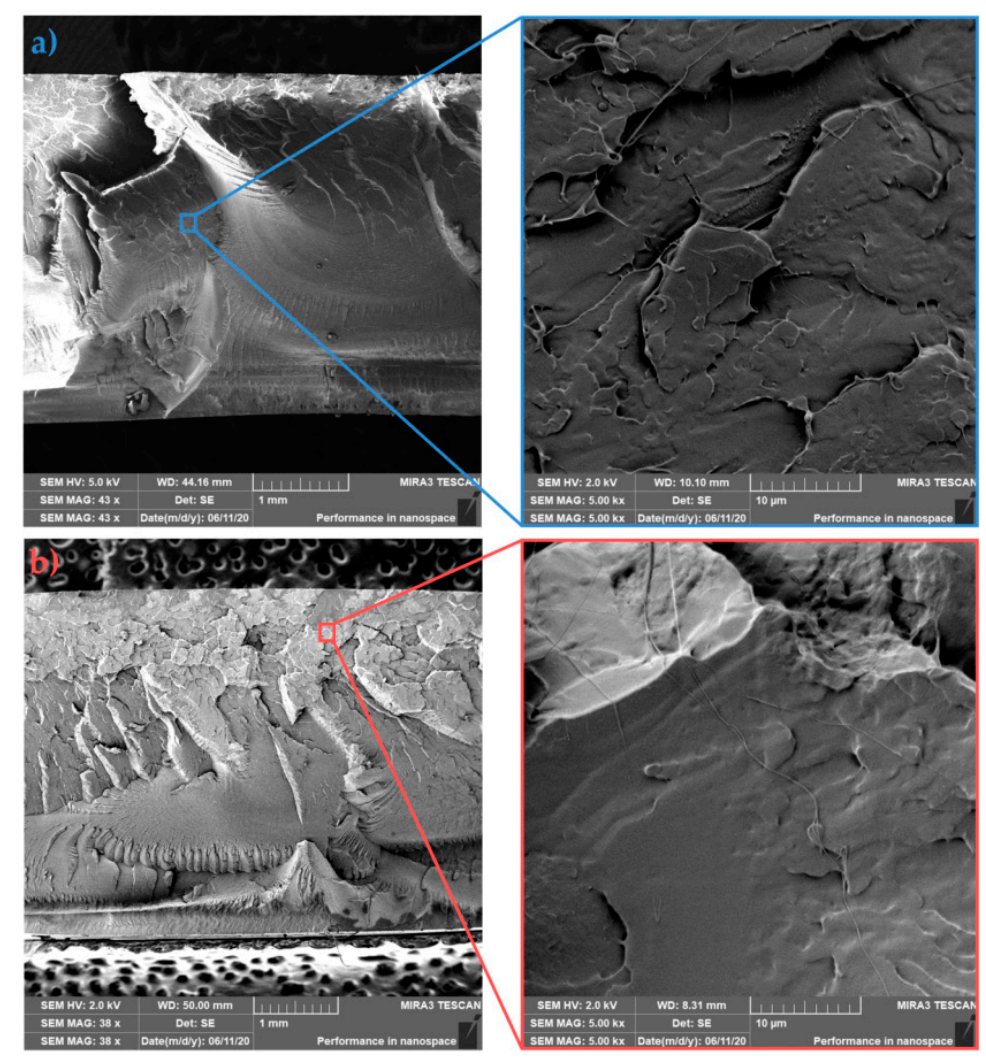

Figure 9. Fracture morphologies of (a) cold and (b) hot mold PLLA. 

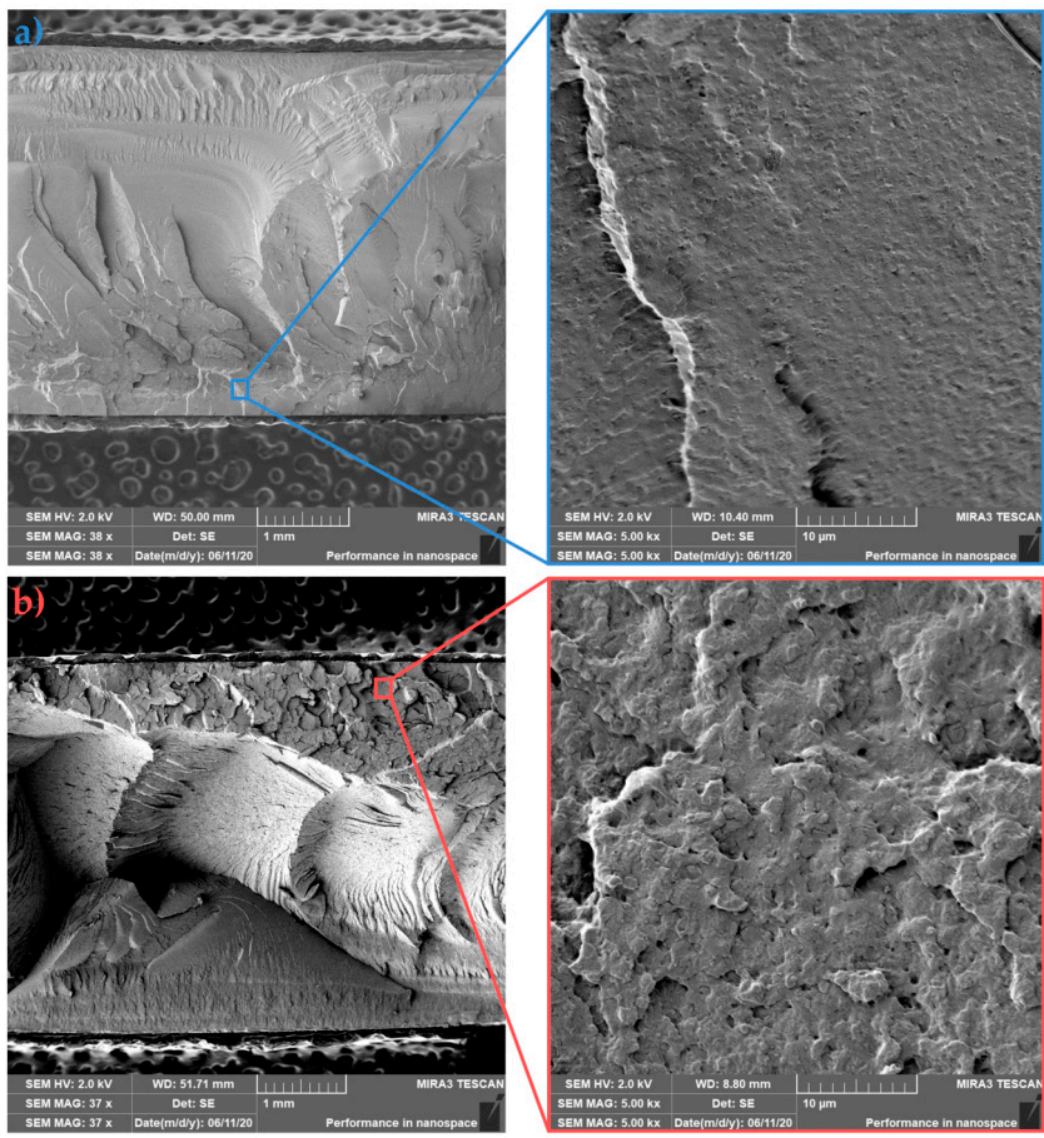

Figure 10. Fracture morphologies of (a) cold and (b) hot mold PLLA/5PDLA.

The morphology of sample fractures with $1 \mathrm{wt} . \%$ HA (PLLA/1HA) is shown in Figure 11a (cold mold) and Figure 11b (hot mold). Similar to the previous samples, a coarser failure with deep concavities can be observed for in-mold annealed samples, reflecting a higher degree of crystallinity and torturous path progression of fracture fronts. Furthermore, both images show relatively good dispersion and distribution of HA (white dots) with just a few agglomerates in the PLLA matrix. In-mold annealed samples show a higher degree of cavitation in the nanofiller region and ductile fibrillation of PLLA. The existence of drawing fibrils and cavitation on the impact fracture surface confirms enhanced impact toughness (see Figure 6). An increase of the temperature in the crack-tip region above the glass transition temperature due to high strain-rate could be behind this kind of fibril formation [55]. Fine dispersion and distribution of HA resulted due to heterogeneous nucleation effect and in-mold annealing in the enhanced microstructure of PLLA/1HA nanocomposite. Furthermore, a possible explanation behind cavitation in HA region could be the hydrogen bonding, which was observed by Zhou et al. [45]. In their study, the IR and XPS analysis showed the formation of hydrogen bonding between the $\mathrm{C}=\mathrm{O}$ group of PDLLA and the surface P-OH group of HA in the PDLLA/HA nanocomposites.

Asymmetric PLLA/5PDLA mixtures with 1 wt.\% HA are shown in Figure 12a (cold mold) and Figure $12 \mathrm{~b}$ (hot mold). The details of nanocomposite figures show relatively good dispersion of the nanofiller for both samples. The fracture surface of PLLA/5PDLA/1HA from cold mold has a similar fractured morphology to that of cold molded PLLA/5PDLA. In contrast, when comparing in-mold annealed PLLA/5PDLA/1HA and PLLA/5PDLA samples, the nanocomposite shows very different fracture morphology after the addition of $1 \mathrm{wt} . \%$ HA. Fracture curves of nanocomposite sample indicate a one-plane fracture, which is perpendicular to the applied load. Furthermore, PLLA/5PDLA/1HA has a less uneven progression of fracture fronts when compared to PLLA/5PDLA. In-mold annealed PLLA/5PDLA/1HA show an increase in impact resistance when compared to the samples 
without HA. On the other hand, the cold mold nanocomposite specimens show a decrease in impact toughness with the addition of $1 \mathrm{wt} . \%$ of HA, when compared to asymmetric blends. When comparing crystallinity degrees of nanocomposites ( $1 \mathrm{wt} . \% \mathrm{HA})$ and blends from both cold and hot molds they are nearly identical. Loose of tight entanglements of macromolecular chains at amorphous fractions due to stereocomplexation and homocrystallization could cause this phenomenon.

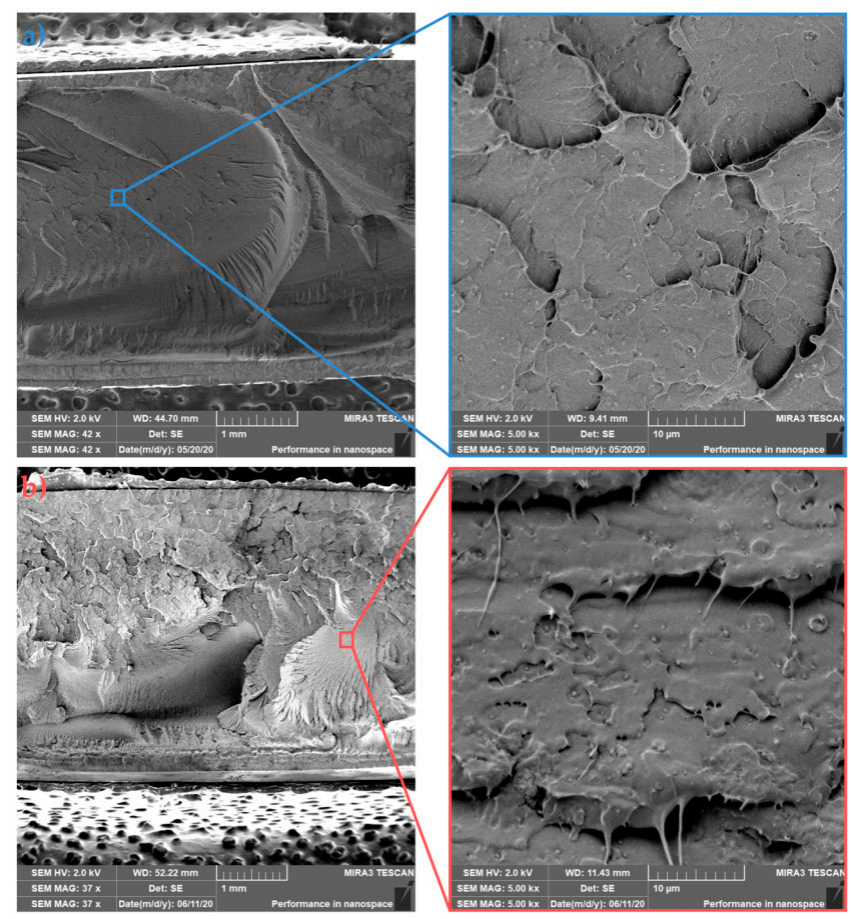

Figure 11. Fracture morphologies of (a) cold and (b) hot mold PLLA/1HA.
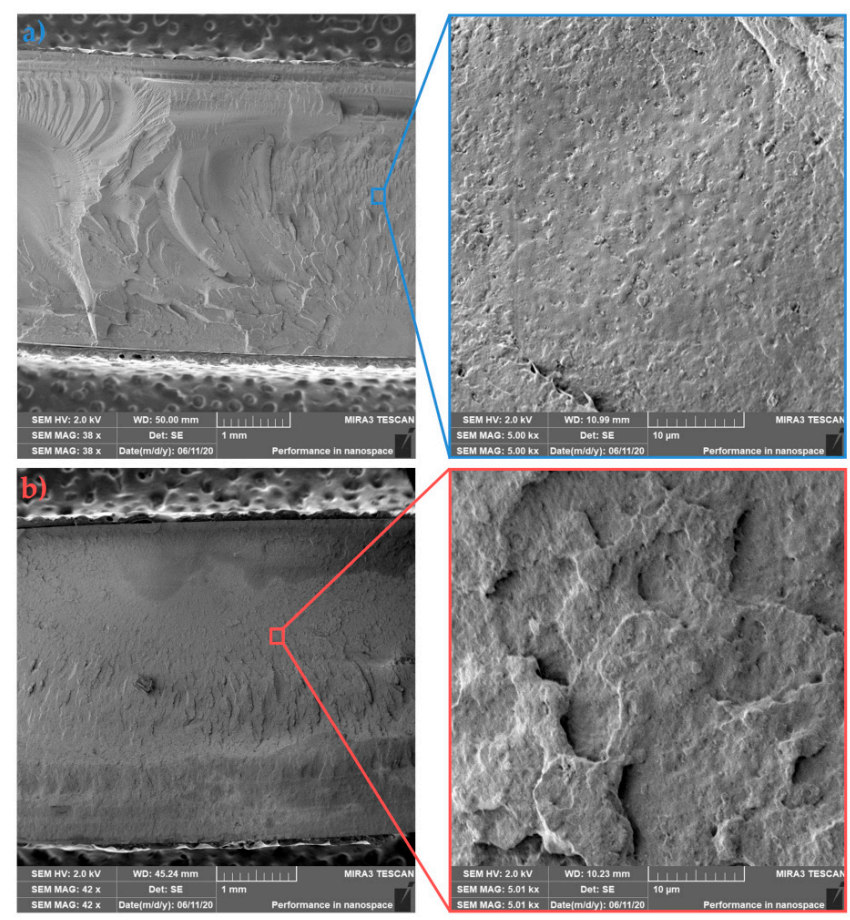

Figure 12. Fracture morphologies of (a) cold and (b) hot mold PLLA/5PDLA/1HA. 
The failure morphology of cold and hot molded samples with $15 \mathrm{wt}$.\% HA (PLLA/15HA) is shown in Figure 13a,b, respectively. The fracture surface of PLLA/15HA from the cold mold shows typical brittle fracture failure of PLLA. The detail of the structure then shows the agglomeration of HA into higher structural units and a large number of cavities where agglomerates were tearing apart by the progression of fracture fronts. Agglomeration of unmodified HA within PLA matrix due to their higher surface energy of nanoparticles has been observed by Ko et al. [39]. In contrast, detail of in-mold annealed sample shows a more compact structure of the fractured surface. The different degrees of crystallinity (see Tables 2 and 3 ) of the cold ( $26 \%)$ and hot ( $51 \%)$ molds do not reflect the previous trend of increasing impact toughness, which remains identical. Thus, the primary mechanism that led to the failure of the samples was the agglomeration of nanofiller into higher structural units that acted as local stress concentrators.
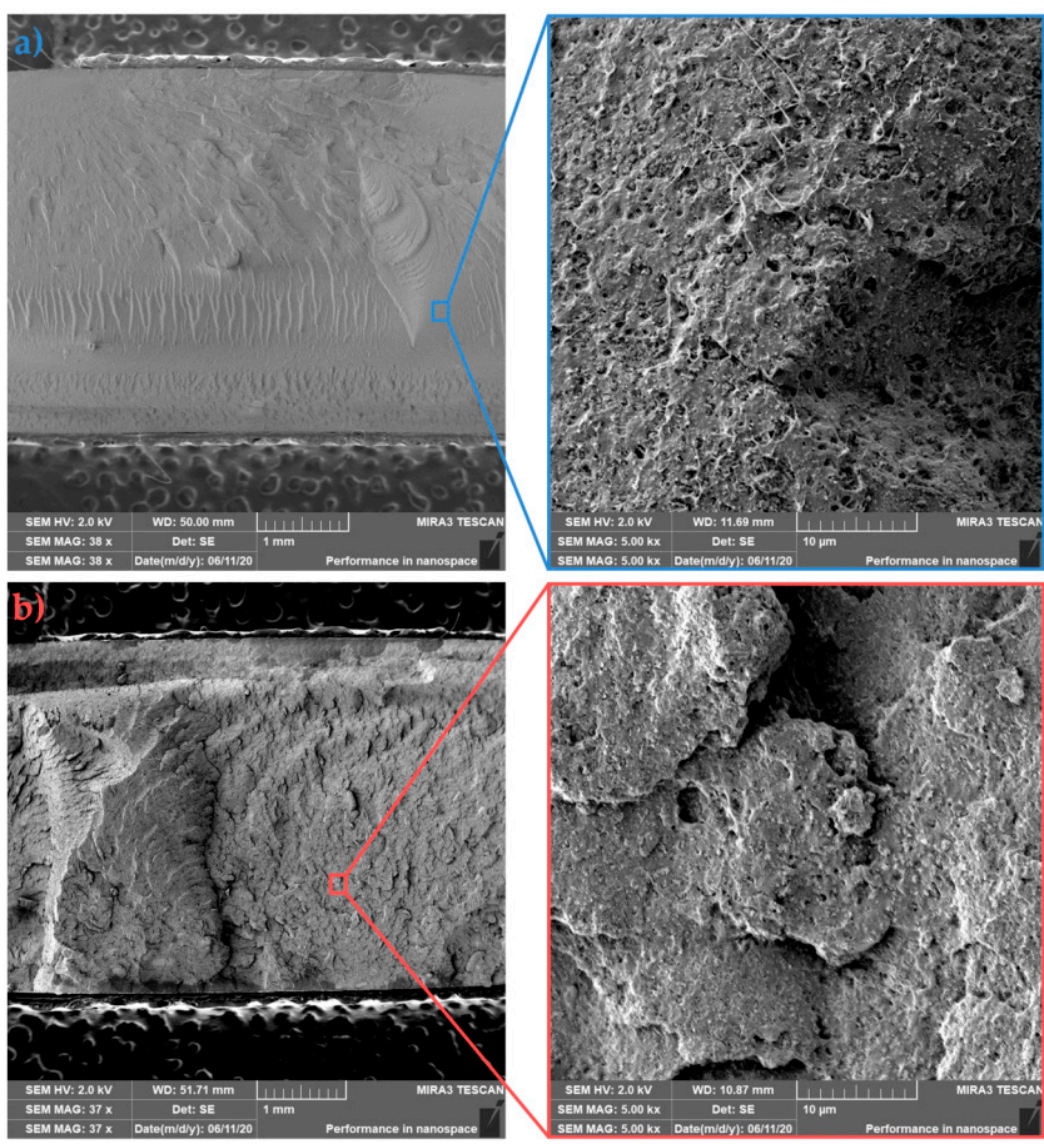

Figure 13. Fracture morphologies of (a) cold and (b) hot mold PLLA/15HA.

Fractured surfaces of cold (Figure 14a) and hot (Figure 14b) molded nanocomposites with $5 \mathrm{wt}$ \% of PDLA, and $15 \mathrm{wt}$ \% of HA showed similar failure mode as PLLA/15HA nanocomposites. The higher concentrations of nanoparticles of HA, while imparting good thermal resistance (see Figures 7 and 8) to the biocomposite, induced lower mechanical properties (except tensile elastic modulus) at higher concentrations. 

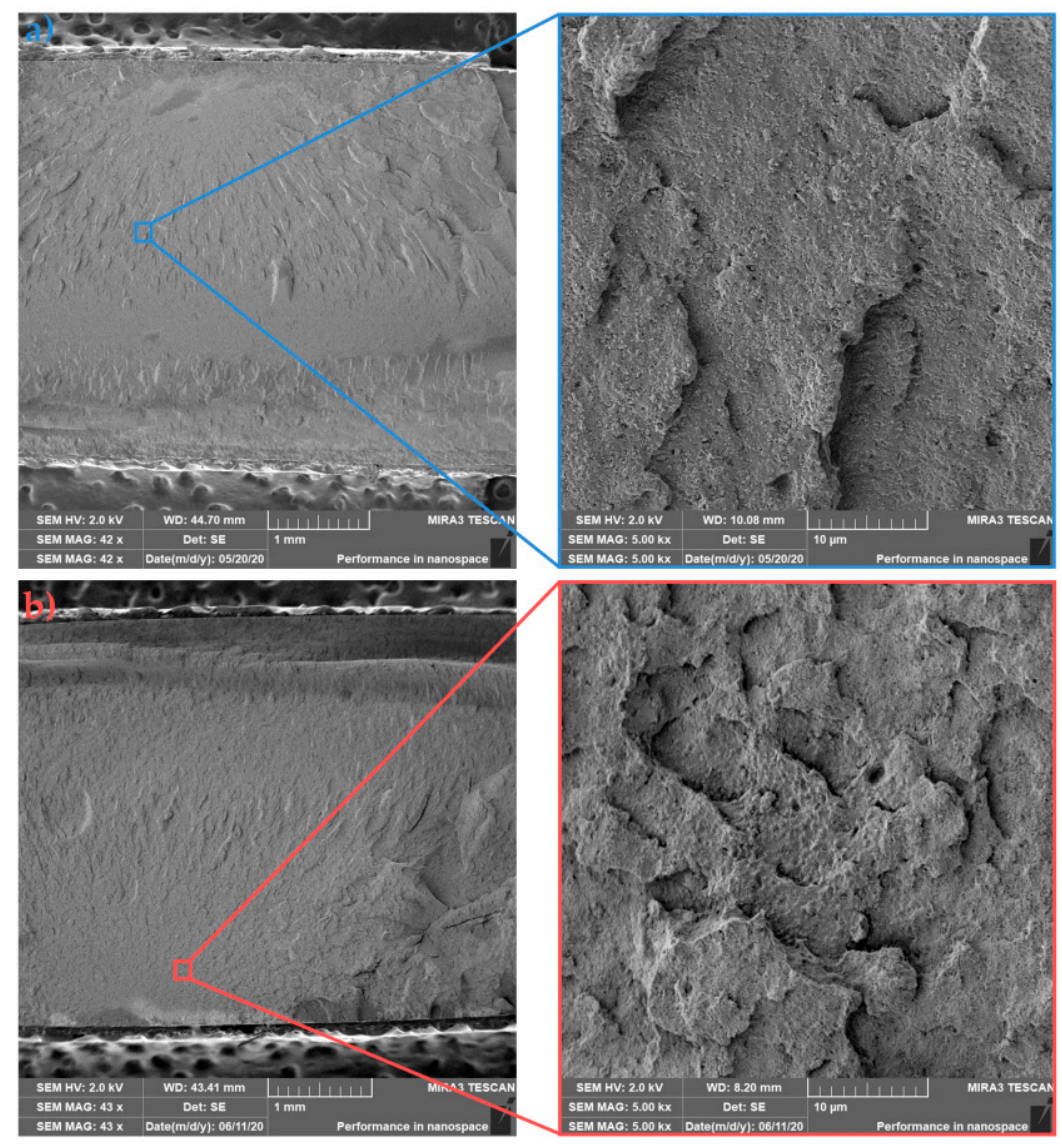

Figure 14. Fracture morphologies of (a) cold and (b) hot mold PLLA/5PDLA/15HA.

\section{Conclusions}

In this work, the effect of in-mold annealing on the properties of nanocomposite systems based on asymmetric poly(L-lactide) (PLLA)/Poly(D-lactide) (PDLA) blends at $5 \mathrm{wt} . \%$ PDLA loading, which were incorporated with nano-hydroxyapatite (HA) at various concentrations (1, $5,10,15 \mathrm{wt} . \%$ ) was presented and discussed. In-mold annealing at $100^{\circ} \mathrm{C}$ mold for $2 \mathrm{~min}$ after injection molding was compared to relatively "cold" molded samples at a temperature of $50^{\circ} \mathrm{C}$. From the results, it was noticed that the tensile modulus, crystallinity, and thermal resistance were enhanced with increasing content of HA and blending with $5 \mathrm{wt} . \%$ of PDLA. In-mold annealing further enhanced the above-mentioned properties due to the synergistic action of specific stereocomplex interactions and increased nucleation rate due to the introduction of HA. In-mold annealed PLLA/5PDLA/15HA samples show an increase of the tensile modulus by $\sim 28 \%$; VST by $\sim 44 \%$; and crystallinity by $\sim 59 \%$, when compared to neat hot molded PLLA. On the other hand, the \% elongation values at the break as well as the tensile strength of the PLLA and asymmetric nanocomposites were lowered with increasing HA content and in-mold annealing. In the case of asymmetric blends and related nanocomposites an embrittlement of material systems has been linked to in-mold annealing. Loose of tight entanglements of macromolecular chains at amorphous fractions due to stereocomplexation and homocrystallization could cause this phenomenon. On the other hand, impact toughness, when compared to neat cold-molded PLLA was improved by $~ 44 \%$ with in-mold annealing of PLLA/1HA. Furthermore, fracture morphology revealed fine dispersion and distribution of $\mathrm{HA}$ at $1 \mathrm{wt} . \%$ concentration. On the other hand, fractured surfaces with a high concentration of HA (15 wt.\%) show agglomerates that worked as stress concentrators during impact loading. This is a clear sign that at higher concentrations of HA, prolonged melt-blending is insufficient to achieve good dispersion and distribution of HA within both PLLA and PLLA/5PDLA blends. 
Author Contributions: Conceptualization, M.B. and C.C.; methodology, M.B.; validation, M.B., C.C. and P.B.; formal analysis, L.B.; investigation, M.B., C.C., L.B. and P.B.; resources, M.B.; data curation, C.C.; writing—original draft preparation, M.B.; writing-review and editing, M.B. and C.C.; visualization, C.C.; supervision, L.B.; project administration, L.B.; funding acquisition, L.B. All authors have read and agreed to the published version of the manuscript.

Funding: This work was supported by the Student Grant Competition of the Technical University of Liberec under the project No. SGS-2019-5015 Research and development for innovation of materials and production technologies with application potential in mechanical engineering. Further funding was supported by the Ministry of Education, Youth and Sports of the Czech Republic and the European Union-European Structural and Investment Funds in the frames of Operational Program Research, Development and Education—project Hybrid Materials for Hierarchical Structures (HyHi, Reg. No. CZ.02.1.01/0.0/0.0/16_019/0000843).

Data Availability Statement: Not applicable.

Acknowledgments: Not applicable.

Conflicts of Interest: The authors declare no conflict of interest.

\section{References}

1. Nagalakshmaiah, M.; Afrin, S.; Malladi, R.P.; Elkoun, S.; Robert, M.; Ansari, M.A.; Svedberg, A.; Karim, Z. Biocomposites: Present trends and challenges for the future. In Green Composites for Automotive Applications; Woodhead Publishing: Sawston, UK, 2019; pp. 197-215.

2. Ganapini, W. Bioplastics: A Case Study of Bioeconomy in Italy; Edizioni Ambiente: Milan, Italy, 2014; ISBN 88-6627-099-7.

3. Watkins, E.; Schweitzer, J.-P. Moving towards a circular economy for plastics in the EU by 2030. In Think 2030. Brussels: Institute for European Environmental Policy (IEEP); IEEP: Brussels, Belgium, 2018.

4. Masutani, K.; Kimura, Y. Present situation and future perspectives of poly (lactic acid). In Synthesis, Structure and Properties of Poly(Lactic Acid); Springer: Cham, Switzerland, 2017; pp. 1-25.

5. Fiorentino, G.; Ripa, M.; Ulgiati, S. Chemicals from Biomass: Technological versus Environmental Feasibility. A Review. Biofuel. Bioprod. Biorefin. 2017, 11, 195-214. [CrossRef]

6. Groot, W.; Van Krieken, J.; Sliekersl, O.; De Vos, S. Production and Purification of Lactic Acid and Lactide. In POLY (LACTIC ACID): Synthesis, Structures, Properties, Processing, and Applications; Wiley: Hoboken, NJ, USA, 2010; Volume 1, pp. 1-18.

7. Lim, L.-T.; Auras, R.; Rubino, M. Processing Technologies for Poly(Lactic Acid). Prog. Polym. Sci. 2008, 33, 820-852. [CrossRef]

8. Reddy, M.M.; Vivekanandhan, S.; Misra, M.; Bhatia, S.K.; Mohanty, A.K. Biobased Plastics and Bionanocomposites: Current Status and Future Opportunities. Prog. Polym. Sci. 2013, 38, 1653-1689. [CrossRef]

9. Tsuji, H. Poly(Lactic Acid) Stereocomplexes: A Decade of Progress. Adv. Drug Deliv. Rev. 2016, 107, 97-135. [CrossRef] [PubMed]

10. Na, B.; Zhu, J.; Lv, R.; Ju, Y.; Tian, R.; Chen, B. Stereocomplex Formation in Enantiomeric Polylactides by Melting Recrystallization of Homocrystals: Crystallization Kinetics and Crystal Morphology. Macromolecules 2014, 47, 347-352. [CrossRef]

11. Tan, B.H.; Muiruri, J.K.; Li, Z.; He, C. Recent Progress in Using Stereocomplexation for Enhancement of Thermal and Mechanical Property of Polylactide. ACS Sustain. Chem. Eng. 2016, 4, 5370-5391. [CrossRef]

12. Ikada, Y.; Jamshidi, K.; Tsuji, H.; Hyon, S.H. Stereocomplex Formation between Enantiomeric Poly (Lactides). Macromolecules 1987, 20, 904-906. [CrossRef]

13. Tsuji, H.; Ikada, Y. Stereocomplex Formation between Enantiomeric Poly(Lactic Acid) s. XI. Mechanical Properties and Morphology of Solution-Cast Films. Polymer 1999, 40, 6699-6708. [CrossRef]

14. Tsuji, H. Poly (Lactide) Stereocomplexes: Formation, Structure, Properties, Degradation, and Applications. Macromol. Biosci. 2005, 5, 569-597. [CrossRef] [PubMed]

15. Yin, H.-Y.; Wei, X.-F.; Bao, R.-Y.; Dong, Q.-X.; Liu, Z.-Y.; Yang, W.; Xie, B.-H.; Yang, M.-B. Enantiomeric Poly(d-lactide) with a Higher Melting Point Served as a Significant Nucleating Agent for Poly(l-lactide). CrystEngComm 2015, 17, 4334-4342. [CrossRef]

16. Luo, F.; Fortenberry, A.; Ren, J.; Qiang, Z. Recent Progress in Enhancing Poly(Lactic Acid) Stereocomplex Formation for Material Property Improvement. Front. Chem. 2020, 8, 688. [CrossRef]

17. Yamane, H.; Sasai, K.; Takano, M.; Takahashi, M. Poly (D-Lactic Acid) as a Rheological Modifier of Poly (L-Lactic Acid): Shear and Biaxial Extensional Flow Behavior. J. Rheol. 2004, 48, 599-609. [CrossRef]

18. Inkinen, S.; Stolt, M.; Södergård, A. Effect of Blending Ratio and Oligomer Structure on the Thermal Transitions of Stereocomplexes Consisting of Ad-lactic Acid Oligomer and Poly (L-lactide). Polym. Adv. Technol. 2011, 22, 1658-1664. [CrossRef]

19. Shi, X.; Jing, Z.; Zhang, G. Influence of PLA Stereocomplex Crystals and Thermal Treatment Temperature on the Rheology and Crystallization Behavior of Asymmetric Poly(L-lactide)/Poly (D-lactide) Blends. J. Polym. Res. 2018, 25, 71. [CrossRef]

20. Wei, X.-F.; Bao, R.-Y.; Cao, Z.-Q.; Yang, W.; Xie, B.-H.; Yang, M.-B. Stereocomplex Crystallite Network in Asymmetric PLLA/PDLA Blends: Formation, Structure, and Confining Effect on the Crystallization Rate of Homocrystallites. Macromolecules 2014, 47, 1439-1448. [CrossRef] 
21. Wang, J.; Lv, R.; Wang, B.; Na, B.; Liu, H. Direct Observation of a Stereocomplex Crystallite Network in the Asymmetric Polylactide Enantiomeric Blends. Polymer 2018, 143, 52-57. [CrossRef]

22. Rasal, R.M.; Janorkar, A.V.; Hirt, D.E. Poly(Lactic Acid) Modifications. Prog. Polym. Sci. 2010, 35, 338-356. [CrossRef]

23. Yang, S.; Leong, K.-F.; Du, Z.; Chua, C.-K. The Design of Scaffolds for Use in Tissue Engineering. Part I. Traditional Factors. Tissue Eng. 2001, 7, 679-689. [CrossRef]

24. Nazhat, S.; Kellomäki, M.; Törmälä, P.; Tanner, K.; Bonfield, W. Dynamic Mechanical Characterization of Biodegradable Composites of Hydroxyapatite and Polylactides. J. Biomed. Mater. Res. 2001, 58, 335-343. [CrossRef]

25. Teo, W.; Liao, S.; Chan, C.; Ramakrishna, S. Fabrication and Characterization of Hierarchically Organized Nanoparticle-Reinforced Nanofibrous Composite Scaffolds. Acta Biomater. 2011, 7, 193-202. [CrossRef]

26. Hanemann, T.; Szabó, D.V. Polymer-Nanoparticle Composites: From Synthesis to Modern Applications. Materials 2010, 3, 3468-3517. [CrossRef]

27. Hasnain, M.S.; Ahmad, S.A.; Chaudhary, N.; Hoda, M.N.; Nayak, A.K. 1-Biodegradable polymer matrix nanocomposites for bone tissue engineering. In Applications of Nanocomposite Materials in Orthopedics; Inamuddin, Asiri, A.M., Mohammad, A., Eds.; Woodhead Publishing Series in Biomaterials; Woodhead Publishing: Sawston, UK, 2019; pp. 1-37. ISBN 978-0-12-813740-6.

28. Bharadwaz, A.; Jayasuriya, A.C. Recent Trends in the Application of Widely Used Natural and Synthetic Polymer Nanocomposites in Bone Tissue Regeneration. Mater. Sci. Eng. C Mater. Biol. Appl. 2020, 110, 110698. [CrossRef]

29. Seunarine, K.; Gadegaard, N.; Tormen, M.; Meredith, D.; Riehle, M.; Wilkinson, C. 3D Polymer Scaffolds for Tissue Engineering. Nanomedicine 2006, 1, 281-296. [CrossRef]

30. Ishii, S.; Tamura, J.; Furukawa, T.; Nakamura, T.; Matsusue, Y.; Shikinami, Y.; Okuno, M. Long-Term Study of High-Strength Hydroxyapatite/Poly(L-Lactide) Composite Rods for the Internal Fixation of Bone Fractures: A 2-4-Year Follow-up Study in Rabbits. J. Biomed. Mater. Res. B App. Biomater. 2003, 66B, 539-547. [CrossRef] [PubMed]

31. Lin, P.-L.; Fang, H.-W.; Tseng, T.; Lee, W.-H. Effects of Hydroxyapatite Dosage on Mechanical and Biological Behaviors of Polylactic Acid Composite Materials. ASC Mater. Lett. 2007, 61, 3009-3013. [CrossRef]

32. Salerno, A.; Fernández-Gutiérrez, M.; del Barrio, J.S.R.; Pascual, C.D. Macroporous and Nanometre Scale Fibrous PLA and PLA-HA Composite Scaffolds Fabricated by a Bio Safe Strategy. RSC Adv. 2014, 4, 61491-61502. [CrossRef]

33. Akindoyo, J.O.; Beg, M.D.; Ghazali, S.; Alam, A.; Heim, H.P.; Feldmann, M. Synergized Poly(Lactic Acid)-Hydroxyapatite Composites: Biocompatibility Study. J. Appl. Polym. Sci. 2019, 136, 47400. [CrossRef]

34. Šupová, M. Problem of Hydroxyapatite Dispersion in Polymer Matrices: A Review. J. Mater. Sci. Mater. Med. 2009, 20, 1201-1213. [CrossRef] [PubMed]

35. Akindoyo, J.O.; Beg, M.D.; Ghazali, S.; Heim, H.P.; Feldmann, M. Effects of Surface Modification on Dispersion, Mechanical, Thermal and Dynamic Mechanical Properties of Injection Molded PLA-Hydroxyapatite Composites. Compos. Part A Appl. Sci. Manuf. 2017, 103, 96-105. [CrossRef]

36. Akindoyo, J.O.; Beg, M.D.; Ghazali, S.; Heim, H.P.; Feldmann, M. Impact Modified PLA-Hydroxyapatite Composites-ThermoMechanical Properties. Compos. Part A Appl. Sci. Manuf. 2018, 107, 326-333. [CrossRef]

37. Hong, Z.; Qiu, X.; Sun, J.; Deng, M.; Chen, X.; Jing, X. Grafting Polymerization of L-Lactide on the Surface of Hydroxyapatite Nano-Crystals. Polymer 2004, 45, 6699-6706. [CrossRef]

38. Hong, Z.; Zhang, P.; He, C.; Qiu, X.; Liu, A.; Chen, L.; Chen, X.; Jing, X. Nano-Composite of Poly(L-lactide) and Surface Grafted Hydroxyapatite: Mechanical Properties and Biocompatibility. Biomaterials 2005, 26, 6296-6304. [CrossRef]

39. Ko, H.-S.; Lee, S.; Lee, D.; Jho, J.Y. Mechanical Properties and Bioactivity of Poly(Lactic Acid) Composites Containing Poly (Glycolic Acid) Fiber and Hydroxyapatite Particles. Nanomaterials 2021, 11, 249. [CrossRef] [PubMed]

40. Shuai, C.; Yu, L.; Yang, W.; Peng, S.; Zhong, Y.; Feng, P. Phosphonic Acid Coupling Agent Modification of HAP Nanoparticles: Interfacial Effects in PLLA/HAP Bone Scaffold. Polymers 2020, 12, 199. [CrossRef] [PubMed]

41. Ferri, J.; Jordá, J.; Montanes, N.; Fenollar, O.; Balart, R. Manufacturing and Characterization of Poly(Lactic Acid) Composites with Hydroxyapatite. J. Thermoplast. Compos. Mater. 2018, 31, 865-881. [CrossRef]

42. Henton, D.E.; Gruber, P.; Lunt, J.; Randall, J. Polylactic Acid Technology. In Natural Fibers, Biopolymers, and Biocomposites, 1st ed.; CRC Press: Boca Raton, FL, USA, 2005; Volume 16, pp. 527-577.

43. Sarasua, J.-R.; Prud'Homme, R.E.; Wisniewski, M.; Le Borgne, A.; Spassky, N. Crystallization and Melting Behavior of Polylactides. Macromolecules 1998, 31, 3895-3905. [CrossRef]

44. Sarasua, J.; Arraiza, A.L.; Balerdi, P.; Maiza, I. Crystallization and Thermal Behaviour of Optically Pure Polylactides and Their Blends. J. Mater. Sci. 2005, 40, 1855-1862. [CrossRef]

45. Zhou, S.; Zheng, X.; Yu, X.; Wang, J.; Weng, J.; Li, X.; Feng, B.; Yin, M. Hydrogen Bonding Interaction of Poly(D,Llactide)/Hydroxyapatite Nanocomposites. Chem. Mater. 2007, 19, 247-253. [CrossRef]

46. Lv, T.; Li, J.; Huang, S.; Wen, H.; Li, H.; Chen, J.; Jiang, S. Synergistic Effects of Chain Dynamics and Enantiomeric Interaction on the Crystallization in PDLA/PLLA Mixtures. Polymer 2021, 222, 123648. [CrossRef]

47. Vadori, R.; Mohanty, A.K.; Misra, M. The Effect of Mold Temperature on the Performance of Injection Molded Poly(Lactic Acid)Based Bioplastic: The Effect of Mold Temperature on the Performance of Injection Molded Poly(Lactic Acid)-Based Bioplastic. Macromol. Mater. Eng. 2013, 298, 981-990. [CrossRef]

48. Kawamoto, N.; Sakai, A.; Horikoshi, T.; Urushihara, T.; Tobita, E. Physical and Mechanical Properties of Poly(L-Lactic Acid) Nucleated by Dibenzoylhydrazide Compound. J. Appl. Polym. Sci. 2007, 103, 244-250. [CrossRef] 
49. Tang, Z.; Zhang, C.; Liu, X.; Zhu, J. The Crystallization Behavior and Mechanical Properties of Polylactic Acid in the Presence of a Crystal Nucleating Agent. J. Appl. Polym. Sci. 2012, 125, 1108-1115. [CrossRef]

50. Kramer, E.J.; Berger, L.L. Fundamental processes of craze growth and fracture. In Crazing in Polymers Vol. 2; Springer: Cham, Switzerland, 1990; pp. 1-68.

51. Renouf-Glauser, A.C.; Rose, J.; Farrar, D.F.; Cameron, R.E. The Effect of Crystallinity on the Deformation Mechanism and Bulk Mechanical Properties of PLLA. Biomaterials 2005, 26, 5771-5782. [CrossRef] [PubMed]

52. Park, S.D.; Todo, M.; Arakawa, K.; Koganemaru, M. Effect of Crystallinity and Loading-Rate on Mode I Fracture Behavior of Poly(Lactic Acid). Polymer 2006, 47, 1357-1363. [CrossRef]

53. Way, J.; Atkinson, J.; Nutting, J. The Effect of Spherulite Size on the Fracture Morphology of Polypropylene. J. Mater. Sci. 1974, 9, 293-299. [CrossRef]

54. Andrews, E. Microfibrillar Textures in Polymer Fibers. J. Polym. Sci. Part A-2 Polym. Phys. 1966, 4, 668-672. [CrossRef]

55. Graham, I.; Marshall, G.; Williams, J. The Fracture Mechanics of Crazes; Springer: Cham, Switzerland, 1973; pp. 261-272. 